\title{
Records on floral biology and visitors of Jacquemontia montana (Moric.) Meisn. (Convolvulaceae) in Mucugê, Bahia
}

\author{
Silva, FO. ${ }^{\mathrm{a}}$, Kevan, SD. ${ }^{\mathrm{b}}$, Roque, ${ }^{\mathrm{a}}{ }^{\mathrm{a}}$,Viana, $B F^{\mathrm{a} *}$ and Kevan, $P G .{ }^{\mathrm{c}}$ \\ aPrograma de Pós-Graduação em Ecologia e Biomonitoramento, Instituto de Biologia, \\ Universidade Federal da Bahia - UFB, CEP 40170-110, Salvador, Bahia, Brazil \\ ${ }^{\mathrm{b}}$ Department of Biology, Wilfrid Laurier University, Waterloo, Ontario, Canada N2L3C5 \\ 'Department of Environmental Biology, University of Guelph, Guelph, ON, Canada, N1G 2W1 \\ *e-mail: blande.viana@gmail.com.
}

Received December 9, 2008 - Aceppeted April 30, 2009 - Distributed August 31, 2010

(With 4 figures)

\begin{abstract}
We present the first records on pollination biology of Jacquemontia montana (Moric.) Meisn. (Convolvulaceae), a widespread climber in the Chapada Diamantina. Our objectives were to (1) characterise flower morphology and biology of J. montana; (2) sample flower visitors and (3) make inferences about potential pollinators, based on foraging behaviour. Observations and sampling were performed on two patches from 8:00 $\mathrm{AM}$ to 3:30 PM, May $15^{\text {th }}$ to $16^{\text {th }}$, 2007. The corolla is bowl shaped, pentamerous, gamopetalous, actinomorphic, and yellow, with a mean diameter of $22.43 \pm 1.81 \mathrm{~mm}$, the depth being variable during flower phases. Stigma receptivity lasted from 8:00 AM-3:30 PM and pollen viability from 9:00 AM-3:30 PM Pollen. showed great decline in number but not in viability during anthesis. Nectarivorous (Coleoptera, Diptera, Hymenoptera) and herbivorous (Orthoptera) insects were found on the flowers. Both male and female bees (Dialictus spp., Robertson 1902) were the most frequent flower visitor. The bees' behaviour, and time spent on flowers, varied according to the resource gathered (i.e., pollen or nectar). The Dialictus species are likely to be the main pollinator of J. montana, considering the frequency, contact with reproductive parts, and carrying only J. montana pollen spread over the ventral part of the thorax, abdomen and legs. Although not quantified, nectar may still be available in the afternoon, considering the behaviour of bees on flowers during this time. Pollen:ovule ration that was1.200:4, suggests facultative xenogamy.
\end{abstract}

Keywords: campo rupestre, Mellitophily, Halictidae, Convolvulaceae.

\section{Registros sobre a biologia floral e visitantes de Jacquemontia montana (Moric.) Meisn. (Convolvulaceae) em Mucugê, Bahia}

\begin{abstract}
Resumo
Apresentamos os primeiros registros sobre a biologia da polinização de Jacquemontia montana (Moric.) Meisn. (Convolvulaceae), uma trepadeira com ampla distribuição na Chapada Diamantina, Bahia. Os objetivos deste estudo foram: (1) caracterizar a morfologia e biologia floral; (2) amostrar os visitantes; e (3) inferir os possíveis polinizadores, baseando-se no comportamento de forrageio. Observações e amostragens foram conduzidas em duas manchas das 8:00 às 15:30 horas, nos dias 15 e 16 de maio de 2007. A corola é amarela, tem forma de disco, pentâmera, gamopétala, actinomorfa. A corola exposta tem largura média de $22,43 \pm 1,81 \mathrm{~mm}$. A receptividade estigmática ocorre das 8:00 às 15:30 horas e a viabilidade polínica das 9:00 às 15:30 horas, se sobrepondo fortemente. O pólen, porém, apresentou forte declínio em número, devido à retirada pelos visitantes, mas não em viabilidade durante a antese. Insetos nectarívoros (Coleoptera, Diptera, Hymenoptera) e herbívoros (Orthoptera) visitaram as flores. Hymenoptera incluiu representantes das famílias Formicidae (formigas) e Halictidae (Dialictus spp.). Machos e fêmeas de Dialictus spp. foram os visitantes mais frequentes. O comportamento e duração das visitas dessas abelhas variaram conforme o recurso coletado (i.e., pólen ou néctar). As espécies de Dialictus foram os polinizadores potenciais de J. montana, considerando sua frequência, contato com órgãos reprodutivos, e pelo fato de carregar apenas pólen de J. montana na superfície ventral do tórax, abdome e pernas. Embora não tenha sido quantificado, o néctar deve estar disponível até o final da tarde, considerando o comportamento das abelhas nas flores nesse período. A relação pólen:óvulo, no valor de 1.200:4, sugere a ocorrência de xenogamia facultativa.
\end{abstract}

Palavras-chave: campo rupestre, Melitofilia, Halictidae, Convolvulaceae. 


\section{Introduction}

Convolvulaceae is a large family with many species distributed in tropical ecosystems such as rain forests, savannas, prairies and deserts (Souza and Lorenzi, 2005). This family is well represented in Brazilian flora comprising 300 species. Five genera are reported for the Chapada Diamantina region: Bonamia DuPetit-Thouars, Cuscuta Dodder, Evolvulus Linnaeus, Jacquemontia (Harley 1986), and from the Mucugê region the species Jacquemontia montana (Moric.) Meisn. and J. velutina (Choisy)

This region is located in central part of Bahia State, at the Setentrional side of Espinhaço Mountain, a group of disjunct mountains, ranging from Minas Gerais State, and in the northerly direction, reaching the channel of São Francisco River. Vegetation growing in Chapada Diamantina is tightly associated with physiographic features of that region, forming a mosaic of vegetation types including cerrado (a type of savanna), campo rupestre, forest and caatinga with great diversity (Misi and Silva, 1994).

Knowledge of the insect-plant interactions in natural ecosystems is scarce, especially concerning the pollination strategies (Kevan, 1991; Kevan and Viana, 2003). In plantpollinator interactions plants develop strategies to attract high quantity and quality of pollinator services, while animals tend to maximise energetic supply during foraging activity (Westerkamp, 1996). In tropical ecosystems, even species with complex morphology and highly specialised to a particular group of pollinators, may receive a wide range of flower visitors (Roubik, 1989; Endress, 1994). The complexity of such interactions in animal pollinated plants relies on the influence of floral morphology, plant density, floral display and other abiotic and biotic factors on pollinator behavior (Dafni et al., 2005). Consequently, different pollinators can vary in how effectively they deposit and remove pollen among flowers (Endress, 1994).

Jacquemontia montana is a very attractive climber with silvery-grey leaves containing white latex, and bright golden yellow flowers with a bowl-shaped corolla. Other members of the family, such as Ipomoea Linnaeus, have a funnel shaped corolla (Harley and Giulietti, 2004). Flowers of Convolvulaceae generally attract a wide range of visitors that include bees as the predominant group. The same findings were obtained from Merremia macrocalyx (Ruiz et Pav.) O'Donell (Neves et al. 2006), Evolvulus glomerulatus Nees and Mart (Sousa et al., 2006) in Lençóis, at Chapada Diamantina region, and Jacquemontia flowers seem to be no exception.

Although J. montana is widespread in the Chapada area of Brazil, there are no records of its flower visitors and potential pollinators. Therefore, the objectives of this investigation were (1) to characterise flower morphology and biology of J. montana; (2) to sample flower visitors and (3) to make inferences about potential pollinators, based on foraging behaviour.

\section{Material and Methods}

\subsection{Study site and population}

Inserted in Caatinga domain, the Chapada Diamantina region, occupies an area of $50.610 \mathrm{~km}^{2}$, with altitude ranging from 200 to $1.800 \mathrm{~m}$. The relief is greatly irregular, showing rocky peaks, sharp slopes, narrow and deep valleys, great plain surfaces in altitude and high hills which are narrow in side and long in length. Due to the special altitudinal conditions the climate is mesotermic (type Cwb), according to the Köppen classification (1936).

The dominant vegetation at the National Park of Mucugê is campo rupestre, which is herbaceous and shrubby vegetation growing upon rock outcrops at elevations above $900 \mathrm{~m}$ (Giulietti and Pirani, 1988). The studied populations of Jacquemontia montana are located at Parque Municipal de Mucugê, Projeto Sempre Viva, State of Bahia, in Northeast Brasil (13 00 ' 05' S and $41^{\circ} 22^{\prime} 19^{\prime}$ ' W), along the trail to Tiburtino River, in campo rupestre vegetation. J. montana grows as single plants or, more frequently, forming patches of vines in rocky and sandy substrates. The stems can grow on the soil or upon shrubs, always in areas of full or nearly full sunlight.

J. montana have simple leaves; alternate, discolourous, ovate-lanceolate, 5-6,5 × 1,5-2,8 cm, acute apex, acuminate, denteate margin, teeths apiculate, rounded at the base, petiole are from $0,6-0,8 \mathrm{~cm}$ long, tomentose, green-cinereous. A voucher specimen is deposited in the Alexandre Leal Costa Herbarium of the Universidade Federal da Bahia (ALCB n' 78224).

\subsection{Flower morphology and biology}

Flower morphology was described in the field and also in the laboratory with a stereomicroscope. Corolla width and depth were measured with a paquimeter, in a sample of 5 flowers. The colour was determined by direct visual observation. Presence of smell was detected by keeping some flowers in vials for 2 hours. Stigma receptivity was determined using peroxidase reaction. Each hour, from 8:00 AM to 3:00 PM, three stigma were emerged in 3\% hydrogen peroxide solution $(n=24)$. Pollen viability was analysed each hour immerging two anthers per flower in $1 \%$ neutral red solution ( $\mathrm{n}=3$ flowers/hour) during the same interval (Dafni et al., 2005). For each slide we counted a sample of a hundred pollen grains. Pollen-ovule ratio was inferred counting the maximum number of ovule/flower and pollen sampled from two anthers $(n=100$ slide $)$ totalling 3 slides/anther. So, the total number of pollen grains in a flower was estimated by multiplying 300 by 5 anthers. The breeding system classification follows Cruden (1977). Nectar was detected with neutral red, but nectar volume and concentration $(n=30)$ could not be sampled because of its small amount.

Presence of nectar guides was checked by exposing flowers to UV photography (Figures 1 to 3). Broad-band monochromatic filters and UV reflecting grey scale was used to detect areas of UV absorption and UV reflection. This can be used to separate the pollinator visual spectrum. J. montana flowers were placed against a black background 

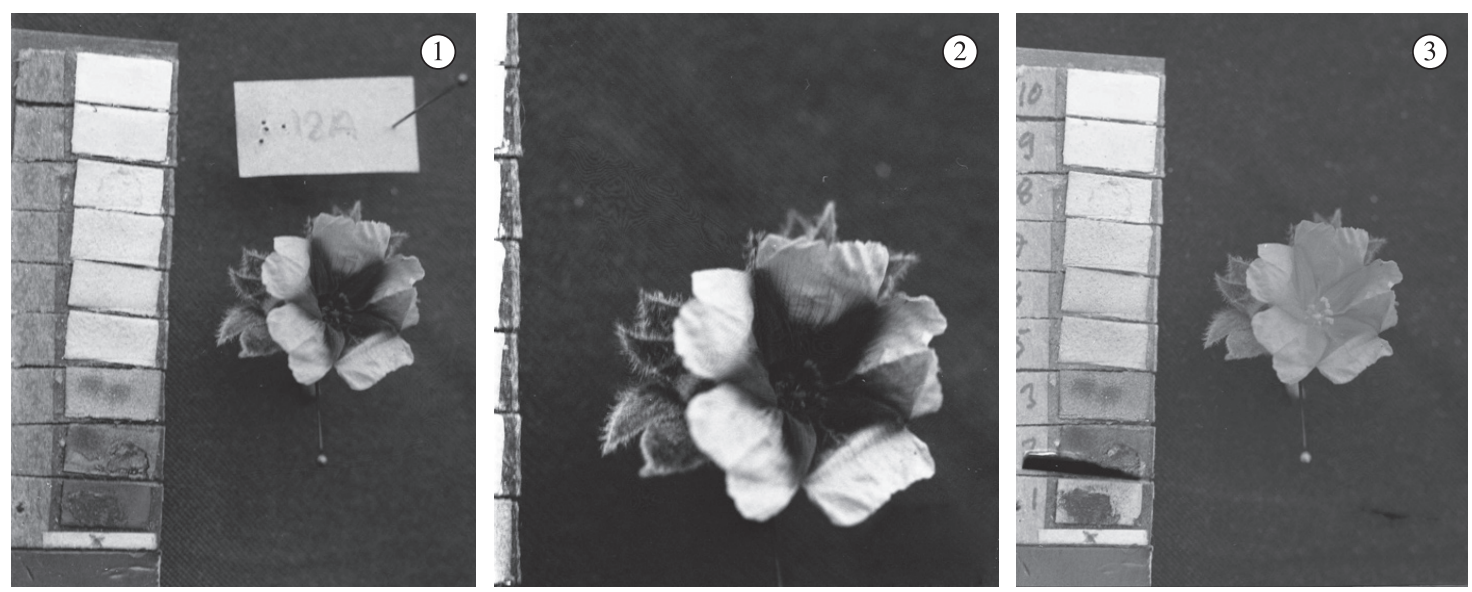

Figures 1-3. The yellow flower of Jacquemontia montana with an utraviolet filter (1-2) and no filter (3). (Photos by Peter G. Kevan).

where the grey scale and labels were affixed. Flowers were photographed, with no filter and ultraviolet filter (KODAK 18A) following methods described by Dafni et al. (2005).

The main biological events in flower scale were recorded in the field by observing individual flowers, from bud until senescence ( $\mathrm{n}=5$ flowers). The events recorded were anthesis time, sequence of corolla opening, changes in corolla colour and shape, time of flower enclosure and longevity; time of maturation of sexual organs, timing and duration of pollen exposure and stigma receptivity; and place of nectar production. Daily number of flowers/inflorescence/ day and number of flowers/plant/day were also quantified $(\mathrm{n}=3$ individual plants). Number of fruits fully formed and aborted ones were quantified in 10 inflorescences from six plants, and presented as a percentage.

\subsection{Flower visitors}

Visitors were collected on flowers using insect nets (diameter $=30.5 \mathrm{~cm})$, in both patches by two people from May $15^{\text {th }}$ to $16^{\text {th }} 2007$. Patch I ( $\mathrm{n}=18$ flowers) and patch II ( $n=16$ flowers) were sampled from 8:00 AM to 3:30 PM Specimens were identified and then deposited at the Insect Collection of "Museu de Zoologia da Universidade Estadual de Feira de Santana", Brazil.

Landing place on flower, resource collected (pollen, nectar or both), mode of resource gathering and time spent in relation to resource were recorded. Pollen grains adhered to Dialictus species were removed using a tooth pick. In order to avoid contamination, each insect caught was kept in a killing jar and then transferred to individual vials. Five slides for each individual bee were prepared and all pollen grains were counted ( $\mathrm{n}=100$ pollen grains/ slide). Pollen types were analysed indicating the percentage of $J$. montana pollen grains. When possible, notes were taken on the number of flowers visited by bees. Visitation ratio was calculated based on number of visits performed by a single bee per flower, each time. Because of sporadic visits and small number of individuals, others insects were not analysed for visitation ratio.

\section{Results}

\subsection{Flower morphology and biology}

The bowl shaped corolla is subsessile, pedicel 1-2 mm long; sepal 5 , connate at the base, 5 to $10 \times 2$ to $4 \mathrm{~mm}$; corolla 5, gamopetalous, actinomorphic, isostemone, epipetalous stamens, alternate with the corolla lobes, ovary bicarpelar, superior, 1 to 2 ovules/locule.

Corolla diameter and depth varied greatly along flower phases, depending on the degree of corolla opening. In the study site, all plants had buds before 8:00 AM, which became gradually inflated around 8:30 AM but with corolla lobes still touching each other at the apix. At 9:00 AM the corolla lobes started to separate and the corolla is half expanded. During two days of observation, most of the flowers were opening in the population between 9:00 to 9:30 AM ( $n=34$ flowers). Flower longevity reached six hours ( $\mathrm{n}=34$ flowers). The thinner corolla lobes start to fold upon each other. In the phase 2, corolla opening is in progress and the mean width was $16.08 \pm 3.94 \mathrm{~mm}$ and mean depth was $12.92 \pm 1.50 \mathrm{~mm}$. During phase 3, when the corolla was fully exposed, the mean width was $22.43 \pm 1.81 \mathrm{~mm}$ and depth was $11.57 \pm 1.13 \mathrm{~mm}$. During phase 4 the corolla gradually closes and the mean width is $17.25 \pm 0.50 \mathrm{~mm}$ and mean depth is $12.75 \pm 0.96 \mathrm{~mm}$. In this phase, the corolla starts to fade and lobes became a whitish color. When the corolla is completely closed the lobes are folded in a central direction (phase 5) and the size is similar to the bud phase.

Flowers are yellow in the visual spectrum but UV pictures showed a clear contrasting pattern. The dark inner part reveals the area of UV absorption, acting as nectar guides to pollinators and nectarivorous insects, contrasting with the UV reflecting are at the outer part (Figures 1 to 3 )

Stigma receptivity ( $\mathrm{n}=21$ flowers) lasted from 8:00 AM to 3:30 PM and pollen viability ( $\mathrm{n}=30$ flowers) lasted from 9:00 AM to 3:30 PM. A hundred percent of viable pollen were found on slides, comprising the period of flower longevity. Total number of pollen grains produced in a 
flower was 1.200. Pollen showed a great decline in number at 1:30 PM, when there was only 1-4 pollen grains on slides. Nectar was available but not quantified ( $n=34$ flowers). Pollen-ovule relation was (1.200/4) indicating facultative xenogamy, with some demand for pollinators.

Inflorescence are glomerule type and axillar, with 2.5 to $3 \mathrm{~cm}$ diameter, bract measure $1.5 \times 0.8 \mathrm{~cm}$, are ovate, acute, tomentose, green-cinereous; bracteole are ovate, acute, with $1.3 \times 0.4 \mathrm{~cm}$, peduncle are $1-3 \mathrm{~cm}$ long. In the studied population, the mean number of inflorescences per plant varied from 5 to 16 (mean was $12.17 \pm 8.08 ; \mathrm{n}=27$ inflorescences). Number of open flowers/day ranged from 10 to 19, with the mean number/plant of $2.17 \pm 1.47(\mathrm{n}=37$ flowers). Fruit is achene, $1.0 \times 0.5 \mathrm{~cm}$, orbicular, green, sepals persistent. The percentage of fully formed fruits/plant was $68.33 \%$ while fruits aborted/plant was $31.66 \%$.

\section{Visitors}

Jacquemontia montana flowers were visited by insects in the orders Coleoptera, Diptera, Hymenoptera and Orthoptera. The Hymenoptera order comprises two families Formicidae (ants) and Halictidae (leafcutter bee). Except for Orthoptera, which feed on flower parts (stamens and corolla), all insects feed on nectar. Male and female small leafcutter bees (Dialictus spp.) were the most frequent flower visitors (Table 1).

Bee behaviour and time spent on flowers ( $\mathrm{n}=12$, for 5 hours period) varied according to the resource gathered (i.e., pollen or nectar). Females collected pollen and nectar, and the males collected only nectar. To get pollen, the bees land on the corolla or at the stamens, moving around the anthers in circular direction or up and down. To reach nectar, bees go deep into the corolla to the nectar disc located at the base of the ovary, spending from up to 10 seconds. To collect pollen, nectar or both, female and male Dialictus sp. spent more than 10 seconds (up to 2 minutes). In consequence, bees touch the stigma when searching for pollen but do not when collecting nectar only.

Daily visitation patterns of Dialictus species showed two main peaks from 10:00 AM to 11:00 AM and a smaller one from 1:00 PM to 2:00 PM. The intense visitation rate at these intervals coincides with the availability of flower resources. Female Dialictus sp. are the first visitors with highest foraging activity from 9:00 AM to 10:30 AM, for pollen and nectar

Table 1. Insect visitors of Jacquemontia montana flowers collected in two consecutive days from 8:00 AM to 3:30 PM, in Mucugê, Bahia.

\begin{tabular}{ccccc}
\hline Order & Family & Species & \multicolumn{2}{c}{ Resources } \\
\cline { 3 - 5 } & & & Nectar & Pollen \\
\hline Coleoptera & Bruchidae & Bruchidae $\mathrm{sp} 1$ & $\mathrm{X}$ & - \\
Diptera & - & Diptera $\mathrm{sp} 1$ & $\mathrm{X}$ & - \\
Hymenoptera & Halictidae & Augochlora $\mathrm{sp} 1$ & $\mathrm{X}$ & - \\
- & - & Dialictus $\mathrm{sp} 1$ & $\mathrm{X}$ & $\mathrm{X}$ \\
- & - & Dialictus $\mathrm{sp} 2$ & $\mathrm{X}$ & $\mathrm{X}$ \\
- & - & Dialictus $\mathrm{sp3}$ & $\mathrm{X}$ & $\mathrm{X}$ \\
- & - & Dialictus $\mathrm{sp} 4$ & $\mathrm{X}$ & $\mathrm{X}$ \\
- & Formicidae & Formicidae $\mathrm{sp} 1$ & $\mathrm{X}$ & - \\
Orthoptera & - & Orthoptera $\mathrm{sp} 1$ & $\mathrm{X}$ & $\mathrm{X}$ \\
\hline
\end{tabular}

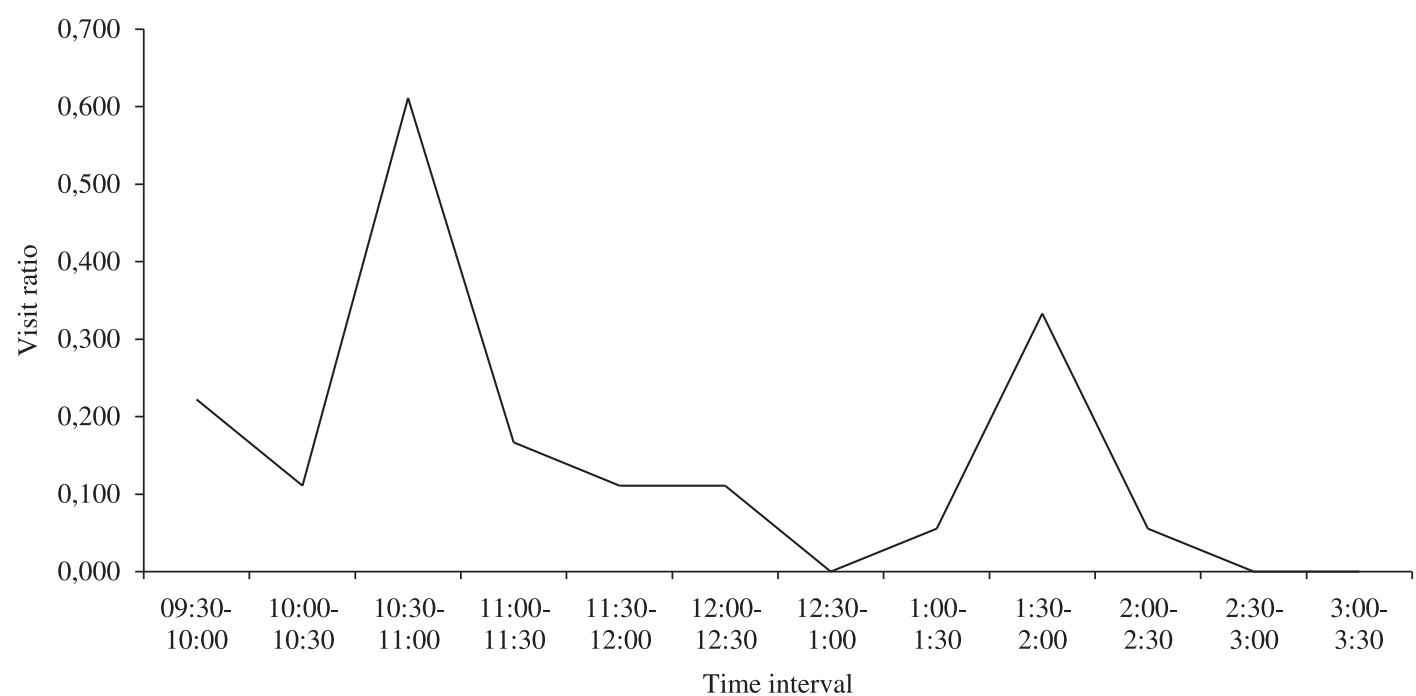

Figure 4. Visitation ratio for Dialictus sp. on Jacquemontia montana flowers, in Mucugê, Bahia. 
collection (Figure 4). Males foraged for longer periods, ranging from 10:30 AM to 3:30 PM, collecting nectar.

Pollen was found to be more abundant during the morning, and almost none was present in the afternoon. Nectar, however, may still be abundant and available in the afternoon, considering the behaviour of bees on flowers and the absence of pollen grains on the bee's body.

Female Dialictus species transported only J. montana pollen type, spread in the ventral body part, including abdomen, thorax and legs, especially the middle and hind legs. These body parts are the ones who touch the stigma during foraging. Augochlora species carried no pollen.

\section{Discussion}

Flower morphology of J. montana allows easy access to pollen and nectar by potential pollinators. Diurnal anthesis, short longevity, and the corolla acting as a landing platform to nectivorous insects, attract pollinators. The yellow corolla is also attractive to pollinators, and the nectar guides indicate to pollinators the location of nectar present. These findings suggest great similarity in flower morphology and biology of J. montana with other Convolvulaceae species studied in campo rupestre region (Sousa et al., 2006; Neves et al., 2006) and caatinga ecosystems (Piedade, 1998).

J. montana flowers can be classified as mellitophylous and, as most Convolvulaceae flowers, is visited by small to medium sized bees from different families. J. montana was visited only by Halictidae bees, and not by Apidae and Anthophoridae as in Merremia macrocalyx (Neves et al., 2006) and Evolvulus glomerulatus Nees \& Mart. (Sousa et al., 2006). The main pollinators of J. multiflora (Choisy) Hallier f. are eusocial bees Apis mellifera Linnaeus 1758 and Trigona spinipes Fabricius 1793 (Piedade-Kiill and Ranga, 2000).

Providing a small number of flowers per inflorescence in a day is a common pattern for Convovulaceae in caatinga (Piedade, 1998) and other vegetation types (Maimoni-Rodella, 1986,1987; Machado and Sazima, 1987; Maimoni-Rodella, 1991; Maimoni-Rodella and Rodella, 1992). Observations on visitation of J. montana, especially for the Dialictus sp., show that flower anthese time appears to be synchronised with the foraging activity. Pollen is actively removed during the morning, and then later in the afternoon when most of the pollen is gone, nectar seems to be the main attraction to flowers.

In this study we did not investigate the reproductive system, so the real role of pollination in performing self or cross pollination was not determined. Investigations for Convolvulaceae family indicate great distribution of self-incompatible systems for genus Ipomoea, most of them esporofitic type (Martin, 1970).

Despite that, other studies recorded the occurrence of self-compatible systems in genus Merremia, Ipomoea and Jacquemontia, as observed in the cogeneric J. multiflora, being cross or self pollinated (Maimoni-Rodella et al., 1982; Maimoni-Rodella and Rodella, 1986; 1986, 1987;
Machado and Sazima, 1987; Maimoni-Rodella, 1991; Maimoni-Rodella and Rodella, 1992; Piedade, 1998; Piedade-Kill and Ranga, 2000), indicating its frequency among this family.

Well established plants of Jacquemontia montana root whenever vines touch the soil, as so in other few species of Convolvulaceae, notably Ipomoea batatas Lam. and Evolvulus nummularius L. (Henderson and Heald, 2001). Data on reproduction of invasive species of Convolvulaceae, such as J. multiflora (Choisy) Hallier f. (Baker, 1974), reveals the dominance of seed germination (Groth, 1991). So, it's notable that in J. montana the percentage of abortion reaches $31.66 \%$, a subject that deserves more investigation to determine if it is caused by an intrinsic feature of the plant or by limiting pollination. More research is needed to determine the need for pollinators and to what extent they contribute to cross pollination in this species.

Aknowledgements - The authors are grateful to the instructors of the $3^{\text {rd }}$ Pollination and Ecology Course and to Dr. T. Woodcock (Wilfrid Laurier University, Waterloo, Ontario) for comments that improved the manuscript and for their support. A special thank you to Dra. Favízia Freitas de Oliveira, Universidade Federal da Bahia, for insect identification. We also thank the monitors Luis Carlos de A. Junior, Gabriel S. Góes, Juliana H. de Sousa, Caroline A. M. Bomfim and Eduardo F. Moreira for field and laboratory support.

\section{References}

BAKER, HG., 1974. The evolution of weeds. Annual Review of Ecology and Systematics vol. 5, p. 1-24.

CRUDEN, RW., 1977. Pollen-ovule rations: a conservative indicator of breeding systems in flowering plants. Evolution, vol. 31, no. 1, p. 32-46.

DAFNI, A., KEVAN, PG. and HUSBAND, BC., 2005. Practical Pollination Biology. Cambridge: Enviroquest. 590 p.

ENDRESS, PK., 1994. Diversity and evolutionary biology of tropical flowers. Cambridge: Cambridge University Press. 511 p.

GIULIETTI, AM. and PIRANI, JR., 1988. Patterns of geographic distribution of some plant species from Espinhaço Range, Minas Gerais and Bahia, Brazil. In VANZOLINI, PE. and HEYER, WR. (Eds.). Proceedings of a Workshop on Neotropical Distribution Patterns. Rio de Janeiro: Academia Brasileira de Ciências. p. 39-69.

GROTH, D., 1991. Morphological characterization of seeds and seedlings of seven weed species of Convolvulaceae occuring in agricultural seeds in Brazil. Iheringia, vol. 41, no. 1, p. 83-99.

HARLEY, RM. and GIULIETTI, AM., 2004. Wild flowers of the Chapada Diamantina. São Carlos: RiMa. 344 p.

HARLEY, RM., 1986. Florula of Mucugê. London: Royal Botanic Gardens Kew. 227 p.

HENDERSON, A. and HEALD, S., 2001. Families of Neotropical Flowering Plants. New York: Botanical Garden; Princeton: Princeton University Press.

KEVAN, PG. and VIANA, BF., 2003. The global decline of pollination services. Biodiversity, vol. 4, no. 4, p. 3-8. 
KEVAN, PG., 1991. Pollination keystone process in sustainable global productivity. Acta Horticulturae, vol. 1, no. 288, p. 103-110.

KOPPEN, W., 1936. Das geographisca System der Klimate. In KOPPEN, W. and GEIGER, G. (Eds.). Handbuch der Klimatologie. Gebrüder: Borntraeger. p. 1-44.

MACHADO, ICS. and SAZIMA, M., 1987. Estudo comparativo da biologia floral em duas espécies invasoras: Ipomoea hederifolia e I. quamoclit (Convolvulaceae). Revista Brasileira de Biologia $=$ Brazilian Journal of Biology, vol. 47, no. 3, p. 425-436.

MAIMONI-RODELLA, RCS. and RODELLA, RA., 1986. Aspectos da biologia floral de Merremia dissecta (Jacq.) Hall. f. var. edentata (Meissn.) O'Donell (Convolvulaceae). Revista de Agricultura, vol. 61, no. 1, p. 213-222.

MAIMONI-RODELLA, RCS. and RODELLA, RA., 1986. Biologia floral de Merremia cissoides (Lam.) Hall F. (Convolvulaceae). Naturalia, vol. 11/12, no. 3 , p. 117-123.

MAIMONI-RODELLA, RCS. and RODELLA, RA., 1992. Biologia floral de Ipomoea acuminata Roem. Et Schult. (Convolvulaceae). Revista Brasileira de Botânica, vol. 15, no. 2, p. 129-133.

MAIMONI-RODELLA, RCS., RODELLA, RA., AMARAL-JUNIOR, A. and YANAGIZAWA, Y., 1982. Polinização em Ipomoea cairica (L.) Sweet. (Convolvulaceae). Naturalia, vol. 7, no. 1-2, p. 167-172.

MARTIN, FW., 1970. Self- and interespecific incomaptibility in the Convolvulaceae. Botanical Gazette, vol. 2, no. 131, p. $130-144$.

MISI, A. and SILVA, MG., 1994. Chapada Diamantina Oriental Bahia: geologia e depósitos. Salvador: Secretaria da
Indústria, Comércio e Recursos Minerais. 194 p. [Série Roteiros Geológicos].

NEVES, EL., TAKI, H., SILVA, FO., VIANA, BF. and KEVAN, PG., 2006. Flower characteristics and visitors of Merremia macrocalyx (Convolvulaceae) in the Chapada Diamantina, Bahia, Brazil. Lundiana, vol. 7, no. 2, p. 97-102.

PIEDADE, LH., 1998. Biologia da polinização e reprodutiva de sete espécies de Convolvulaceae na caatinga do Sertão de Pernambuco. Campinas: Universidade Estadual de Campinas. 123 p. [PhD. Thesis].

PIEDADE-KIILL, LH. and RANGA, NT., 2000. Biologia floral e sistema de reprodução de Jacquemontia multiflora (Choisy) Hallier f. (Convolvulaceae). Revista Brasileira de Botânica, vol. 23 , no. 1 , p. $37-43$.

ROUBIK, DW., 1989. Ecology and Natural History of Tropical Bees. Cambridge: Cambridge University. 514 p.

SOUSA, JH., LEAL, SM. and SAMPAIO, JA., 2006. Aspectos da biologia floral e visitantes de Evolvulus glomerulatus Nees \& Mart (Convolvulaceae) no município de Lençóis, Chapada Diamantina, BA. In VIANA, BF. and FREITAS, FO. (Eds.). Biologia e Ecologia da Polinização: cursos de campo. Salvador: EDUFBA. p. 101-108.

SOUZA, VC. and LORENZI, H., 2005. Botânica Sistemática: guia ilustrado para identificação das famílias de Angiospermas da flora brasileira, baseado em APG II. Nova Odessa: Instituto Plantarum. 640 p.

WESTERKAMP, CH., 1996. Pollen in bee-flower relations: some considerations on melittophily. Botanica Acta, vol. 109, p. $325-332$. 